\title{
MODULATION OF ARA-C-INDUCED APOPTOSIS IN LEUKEMIA BY THE PKC ACTIVATOR BRYOSTATIN 1
}

\author{
Steven Grant ${ }^{1}$ \\ Division of Hematology/Oncology, Departments of Pharmacology and Microbiology, Medical College of Virginia
}

TABLE OF CONTENTS

1. Abstract

2. Introduction

3. ara-C

4. Bryostatin 1

5. Bryostatin 1/ara-C interactions

5.1 Biochemical interactions

5.2 Signalling interactions

5.3 Differentiation and apoptosis

5.4 Sequence-dependent interactions

5.5 Role of $c-M y c$

5.6 Involvement of $\mathrm{Bcl}-2$

6. Future directions

7. Perspectives

8. Acknowledgements

9. References

\section{ABSTRACT}

Modulation of ara-C-induced apoptosis in human leukemia cells by the macrocyclic lactone PKC activator bryostatin 1 occurs at multiple levels, and involves a variety of oncogenes and signalling pathways. Under some circumstances, bryostatin 1 may lead to enhanced conversion of ara-C to its lethal metabolite, ara-CTP. However, bryostatin 1 is able to potentiate ara-C-mediated cytotoxicity in the absence of metabolic perturbations, presumably by modulating the cell death pathway itself. For example, chronic exposure of cells to bryostatin 1 leads to PKC down-regulation, which may alter the balance between survival (e.g., ERK) versus stress (e.g., SAPK/JNK)-related pathways. The ability of bryostatin 1 to enhance ara-C-mediated apoptosis is inversely related to its capacity to induce leukemic cell maturation and may involve the failure to down-regulate expression of the cell cycle progression-related proto-oncogene, $c$-myc. Finally, recent evidence suggests that bryostatin 1 may act, through modification of Bcl-2 phosphorylation status, at a distal site in the cell death pathway. These studies could provide a paradigm important for understanding the mechanism(s) by which agents acting through signal transduction pathways modulate cytotoxic drug-induced cell death.

Received 5/23/97; Accepted 5/28/97

1 To whom correspondence should be addressed at: Medical College of Virginia, MCV Station Box 230, Richmond VA, 23298. Tel: 804-828-5211 Fax: 804-8288079 E-mail:stgrant@vgems.vcu.edu

\section{INTRODUCTION}

The last decade has witnessed a significant increase in interest in a sequence of events referred to as programmed cell death, or apoptosis. Apoptosis is known to play an important role in various aspects of cell biology, including development, immunology, and senescence, among many others. It represents an active, energydependent process in which a cell commits itself to an organized program of self-destruction (1). An important characteristic of apoptosis is that it can be regulated, at least in its initial stages, by a variety of genes whose products govern the activity of diverse cellular signal transduction pathways. As a consequence of this relationship, the cell death pathway is susceptible to pharmacologic manuipulation capable either of promoting or antagonizing cellular survival.

Apoptosis has particular relevance for cancer treatment, particularly that involving hematologic malignancies. Hematopoietic cells have long been known to undergo a classic apoptotic form of cell death when subjected to adverse conditions, such as growth factor deprivation (2). In contrast, tumors of epithelial cell origin tend to be relatively resistant to apoptosis, at least in its classic form (3). In leukemic cells, a very wide range of antineoplastic agents, acting by a variety of mechanisms, induce apoptosis in vitro (4). The potential importance of this phenomenon has been underscored by the identification of apoptotic cells in the peripheral blood of leukemic patients receiving cytotoxic chemotherapy (5).

The concept of modulation of drug-induced apoptosis in leukemia has a precedent in what has been 
referred to as biochemical modulation. In biochemical modulation, antineoplastic agents are combined in such a way as to maximize drug metabolism and achieve antitumor synergy. A classical example is the combination of an inhibitor of de novo pyrimidine biosynthesis with a nucleoside analog i.e., thymidine and 1- -Darabinofuranosylcytosine (ara-C) (6). While similar in some respects to this approach, the strategy of modulating apoptosis has a fundamentally different basis. Thus, instead of augmenting the metabolism of the target drug, the modulating agent would act primarily to lower the threshold of the apoptotic process itself. Recentlly, interest in the development of such modulating agents has focused on the calcium- and lipid-dependent serine/threonine kinase, protein kinase C (PKC) (7). A prototypical example of this strategy has been the combination of the $\mathrm{PKC}$ activator bryostatin 1 and ara-C, which has been shown to exert schedule-dependent antileukemic synergism in several leukemic cell systems $(8,9)$. The purpose of this review is to summarize what is known about the interaction between these agents, and to speculate about the basis for their synergism in light of existing knowledge. Such information could provide a rationale for the development of an entirely novel strategy for the treatment of leukemia and perhaps other hematologic and non-hemtological malignancies.

\section{ARA-C}

The deoxycytidine analog ara- $\mathrm{C}$ is among the most effective agents used in the treatment of acute leukemia in man (10). It is transported across the cell membrane by facilitated nucleoside diffusion (11), and converted to its nucleoside monophosphate derivative, araCMP, by the pyrimidine salvage pathway enzyme, deoxycytidine kinase. This process represents the rate limiting step in ara-C metabolism (12), and has been reported to involve, at least in in vitro systems, participation of the PKC $\alpha$ isoform (13). The metabolism of ara-C and its derivatives are opposed by degradative enzymes such as cytidine deaminase and deoxycytidylate deaminase, which convert them to inactive ara-U catabolites (14). ara-C is ultimately converted to ara-CTP, which is an inhibitor of DNA polymerase $\alpha$ and $\beta$ (15), and is also incorporated into elongating strands, thereby interfering with chain elongation and inducing premature chain termination (16). The lethal actions of ara-C correlate closely with its incorporation into DNA (17), and the bulk of evidence suggests that it is this phenomenon, rather than inhibition of DNA polymerase, that leads to cell death.

The metabolism of ara-C is also linked to perturbations in levels of intracellular lipid messengers that regulate apoptosis. For example, conversion of araCTP to ara-CDP involves a reversal of the cholinephosphotransferase reaction, which leads to the generation of diacylglyceride (DAG) (18). DAG is a potent activator of $\mathrm{PKC}$, which may explain reported increases in activity of this enzyme in ara-C-treated leukemic cells (19). Since PKC serves to oppose apoptosis in hematopoietic cells (20), elevations in DAG activity could theoretically antagonize ara-C-mediated cell killing. Treatment of leukemic cells also leads to the generation of ceramide (21), which is known to be a strong inducer of apoptosis in multiple cell lines $(22,23)$. Thus, the lethal actions of ara-C may be regulated by its net effect on proversus anti-apoptotic lipid messengers.

Resistance of leukemic cells to ara-C, as in the case of virtually all antineoplastic drugs, may occur at two distinct levels. The first level is drug-specific, and involves alterations in drug metabolism or interaction with cellular targets. In the case of ara-C, resistance has been correlated with decreased transport (24), diminished activity of deoxycytidine kinase (25), increased activity of cytidine deaminase (26), increased rates of ara-CTP dephosphorylation (27), increased intracellular levels of dCTP (28), and reduced incorporation of ara-C into DNA (29). However, resistance to ara-C can also result from a generalized reduction in the susceptibility of cells to an apoptotic cell death. For example, increased leukemic cell expression of the proto-oncogene $b c l-2$ confers resistance to a broad range of cytotoxic drugs, including ara-C (30). Cells expressing increased levels of the Bcl-2 protein are less susceptible to ara-C-related activation of proteases involved in the degradation phase of apoptosis, particularly the Yama protease (CPP32) (31,32). Diminished sensitivity of Bcl-2-overexpressing cells to ara-C-mediated lethality occurs in the absence of alterations in ara-C metabolism or the degree of DNA damage (33), supporting the notion that resistance stems from a distal defect in the cell death pathway.

\section{BRYOSTATIN 1}

Bryostatin 1 is a macrocyclic lactone derived from the marine organism Bugula neritina (34). It was initially identified in the NCI's marine product discovery program, and was found to have activity against a variety of hematopoietic and non-hematopoietic tumor cells both in vitro and in vivo (35-38). Based upon this activity, several phase I trials of bryostatin 1 in humans have been completed (39-41), and phase II trials are currently underway.

Bryostatin 1 shares several features with tumorpromoting phorbols such as phorbol 12-myristate 13acetate (PMA) in that it binds to and activates protein kinase $\mathrm{C}$, thereby inducing enzyme translocation to membrane and nucleus (42). The actions of bryostatin 1, like those of PMA, are synergistically enhanced by agents like calcium ionophore (A23187) which increase the availability of intracellular calcium $\left(\left(\mathrm{Ca}^{2+}\right) \mathrm{i}\right)(43)$. In this way, A23187 mimics activation of phospholipase $\mathrm{C}$, which results in generation of $\mathrm{IP}_{3}$ and liberation of $\left(\mathrm{Ca}^{2+}\right)$ i. However, bryostatin 1 exhibits a different spectrum of activity from the phorbols, and in fact blocks certain 
phorbol-associated actions that it does not share, including tumor promotion (44) and induction of leukemic cell differentiation (45). The unique characteristics of bryostatin 1 may stem from specific patterns of PKC isoform activation (46) or nuclear translocation (47). Alternatively, they may result from bryostatin 1's capacity to induce profound PKC down-regulation (48), a consequence of enzyme ubiquitinization and proteasomal degradation (49).

Bryostatin 1 has been shown to exert pleiotropic effects on leukemic cell differentiation. For example, bryostatin 1 induces maturation in some human promyelocytic leukemic (HL-60) sublines, but not others (50,51). Bryostatin 1 may also trigger a differentiation program in the human monocytic leukemia cell line U937, but its actions are considerably weaker than those of PMA (52). Against primary human leukemic cell cultures, bryostatin 1 inhibits both clonogenicity and self-renewal capacity $(53,54)$. In contrast to inhibitory effects toward leukemic cells, bryostatin 1 stimulates the in vitro growth of normal hematopoietic progenitors $(55,56)$, although accessory cell actions have been invoked to account for this effect (57). The basis for bryostatin 1's antileukemic selectivity remains to be established.

\section{BRYOSTATIN 1/ARA-C INTERACTIONS}

\subsection{Biochemical interactions}

Initial studies examining the interaction between bryostatin 1 and ara-C were prompted by the discoveries that both bryostatin 1 (54) and ara-C (58) are highly inhibitory to leukemic cell self-renewal capacity, a biological determinant that correlates closely with clinical outcome in patients with acute leukemic (59). In addition, an accumulating body of evidence indicates that administration of DNA-damaging drugs in conjunction with differentiation-inducing agents often leads, in a sequence-dependent manner, to potentiation of cell death (60-63). Consequently, it is reasonable to propose that the combination of these agents might exhibit even greater antileukemic activity.

Initial empiric studies employing primary cultures of human AML cells did in fact demonstrate that pretreatment of cells with bryostatin $1(10 \mathrm{nM} ; 24 \mathrm{hr})$, with or without the hematopoietic growth factor rGM$\mathrm{CSF}$, followed by ara-C resulted in a marked reduction in primary colony formation (L-CFU) (54). In addition, such combinations virtually abrogated the self-renewal ability of these cells (PE-2 capacity). Interestingly, the same drug exposures were considerably less inhibitory toward the in vitro growth of normal committed (CFU-GM) and early (HPP-CFU) hematopoietic progenitor cells (54). This suggests that the antileukemic selectivity of bryostatin 1 , administered as a single agent, may also apply to its modulatory effects toward cytoxic drugs.
Subsequent studies were conducted to determine if bryostatin 1 might increase ara-C-related inhibitory effects by potentiating drug metabolism. In primary leukemic blast samples, bryostatin 1 exerted a heterogeneous effect on ara-CTP formation, although significant increases in ara-C activation were noted in a subset of samples (64). In the human leukemic cell line HL-60, pretreatment of cells with $10 \mathrm{nM}$ bryostatin 1 for $24 \mathrm{hr}$ increased the formation of ara-CTP after a 6-hr exposure to $10 \mu \mathrm{M}$ ara-C, but only when cells were cultured under plateau phase conditions (cell density $10^{6}$ cells/ml) (65). In contrast, under log phase conditions (cell density $5 \times 10^{5}$ cells $/ \mathrm{ml}$ ), no potentiation was observed. A possible explanation for these findings is that cell cyclerelated changes in plateau phase cells (i.e., decrease in the S-phase fraction) or exhaustion of nutrients leads to reduction in activity of deoxycytidine kinase activity, the enzyme catalyzing the rate-limiting step in ara-C metabolism. Under these circumstances, adminstration of bryostatin 1 may provide a signal that prevents the accompanying inhibition of ara-C phosphorylation. It may also be relevant that the initial phosphorylation step in ara-C metabolism has been found to be dependent upon $\mathrm{PKC}$, at least under in vitro conditions (18).

\subsection{Signalling interactions}

Further insights into the mechanism by which bryostatin 1 might modulate cellular susceptibility to ara-C arose from studies in logarithmically growing HL-60 cells. It was found that in such cells, pretreatment with $10 \mathrm{nM}$ bryostatin 1 for $24 \mathrm{hr}$ (and, to a lesser extent, phorbol dibutyrate) significantly increased the degree of DNA fragmentation and induction of apoptotic morphologic changes resulting from a $6-\mathrm{hr}$ exposure to $10 \mu \mathrm{M}$ ara-C $(66,67)$. These effects correlated with the extent of PKC down-regulation, suggesting that one of the mechanisms by which such agents might potentiate drug-mediated lethality involves overcoming the protective effect of PKC. Support for this concept was provided by the observations that (1) acute exposure to bryostatin 1, which was associated with an increase in PKC activity, opposed araC-mediated apoptosis; and (2) increases in PKC activity induced by membrane-permeable synthetic diacylglycerides (e.g., $\mathrm{diC}_{8}$ ) or phospholipase $\mathrm{C}$ opposed ara-C-related apoptosis (67). Additional evidence that PKC opposes apoptotic events is provided by the observations that tumor-promoting phorbol esters (e.g., PMA) oppose drug-induced apoptosis in hematopoietic cells (68), and that PKC inhibitors induce leukemic cell apoptosis (69) and faciliate drug-induced cell death (70). Thus, the ability of ara-C to trigger leukemic cell apoptosis may be enhanced by two separate but related mechanisms: direct inhibition by PKC inhibitors, and down-regulation by chronic exposure to PKC activators such as bryostatin 1. Although the mechanism by which PKC activity promotes cell survival is unknown, it may be related to perturbations in the level of activity of opposing cell signalling pathways. For example, exposure of cells to ionizing radiation, TNF, and chemotherapeutic agents 
leads to activation of stress-activated protein kinases (SAPK/JNK; p46/p54)(71), whereas survival signals are associated with activation of extracellular receptor kinaserelated pathways (EFK/MAPK/p42/p44) (72). PKC activity has recently been linked to activation of the latter pathway through the generation of sphingosine-1phosphate (73). In view of evidence that cellular susceptibility to apoptosis may depend upon the net balance between stress- versus survival-related signalling pathways (74), it is conceivable that a reduction in PKC activity by bryostatin 1 favors a typical stress response after ara-C exposure.

\subsection{Differentiation and apoptosis}

In leukemia cells, a complex relationship exists between differentiation and apoptosis. Following exposure to inducers of maturation such as retinoic acid and PMA, leukemic cells undergo differentiation and ultimately die an apoptotic death, primarily as a late event. (75,76). On the other hand, induction of leukemic cell maturation (e.g., by PMA) can reduce their susceptibility to induction of apoptosis by agents such as VP-16 (77). In addition, leukemic cells exhibiting dysregulation of PKC respond to PMA by undergoing apoptosis rather than maturation (78). Based upon such evidence, it has been postulated that apoptosis represents an alternative pathway for cells unable to engage a normal differentiation program (79).

These considerations have implications for attempts to understand the interaction between bryostatin 1 and ara-C. For example, in HL-60 cells immune to bryostatin 1's differentiation-inducing actions, pretreatment with bryostatin 1 potentiates ara-C-induced apoptosis (65). It has recently been shown that coadministration of A23187 with bryostatin 1 partially restores the ability of HL-60 cells to undergo differentiation (80). Interestingly, when A23187 was combined with bryostatin 1, it abrogated bryostatin 1related potentiation of ara-C-mediated apoptosis. Coadministration of the organotellurium compound AS101 also enhanced induction of HL-60 cell differentiation by bryostatin 1, although its effects were weaker than those of A23187 (81). The combination of bryostatin 1 and AS101 also failed to potentiate ara-C-induced apoptosis. These findings suggest that a reciprocal relationship exists between bryostatin 1-induced maturation and potentiation of apoptosis, in that interventions that restore bryostatin 1 's capacity to induce differentiation prevent potentiation of cell death. It is important to note that while A23187 and AS101 reduced the ability of bryostatin 1 to augment ara$\mathrm{C}$-induced apoptosis, they resulted in a further decline in clonogenicity $(80,81)$. This suggests that differentiation and apoptosis represent alternative pathways by which leukemic cell self-renewal capacity may be inhibited.

\subsection{Sequence-dependent interactions}

It has been shown by several investigators that exposure of leukemic cells to DNA damaging agents followed by a differentiation-inducing stimulus leads to potentiation of cell death (82-84). The mechanism underlying this phenomenon is unknown, but has been postulated to stem from differentiation-related inhibition of DNA repair (84). Studies in an HL-60 cell line essentially immune to bryostatin 1 's differentiationinducing actions demonstrated that exposure of cells to bryostatin 1 after ara-C failed to enhance apoptosis (65). In contrast, in the monocytic leukemic cell line U937, which is weakly differentiation-responsive to bryostatin 1 (52), pretreatment with bryostatin 1 failed to increase araC-related apoptosis, whereas exposure to ara-C followed by bryostatin 1 did lead to a significant increase in cell death (85). The sequence-dependent nature of the bryostatin 1-ara-C interactions raises the possibility that factors other than, or in addition to, biochemical perturbations (e.g., cell cycle-related events) may contribute to the observed enhancement of apoptosis.

\subsection{Role of c-Myc}

The proto-oncogene $c-M y c$, encodes a protein (cMYC) intimately involved in cell cycle progression and differentiation (86). A recent study has identified the phosphatase cdc25 as a potentially important down-stream target of $c$-myc (87). Bryostatin 1 induces $c$-myc downregulation in human leukemic cells susceptible to maturation induction $(50,88)$, whereas it fails to reduce $c$ myc expression in cells unresponsive to its differentiating actions $(50,88)$. Furthermore, inappropriate expression of $c-m y c$ has been linked to induction of apoptosis under certain adverse conditions (e.g., growth factor deprivation) (89). These observations raise the possibility that the inability of bryostatin 1 to induce $c-m y c$ down-regulation may contribute to its capacity to promote ara-C-related apoptosis. To test this possibility, antisense oligodeoxyribonucleotides (AS-ODN) directed against $c$ $m y c$ were employed to reduce c-MYC expression in bryostatin 1-treated cells, and to determine what effect this might have on ara-C-related apoptosis. It was found that a reduction in levels of c-MYC had no effect on ara-Crelated apoptosis itself, but abrogated the ability of bryostatin 1 to potentiate ara-C-induced cell death (90). These findings support the notion that the failure of bryostatin 1 to reduce expression of c-MYC contributes to its modulatory effects on ara-C-related apoptosis.

\subsection{Involvement of Bcl-2}

Bcl-2 represents a member of a family of proteins that reciprocally regulate cell death (91). Antiapoptotic proteins include Bcl-2, Bcl-xL, Mcl-1, and A1; pro-apoptotic proteins include $\mathrm{Bax}, \mathrm{Bad}, \mathrm{Bak}$, and $\mathrm{Bcl}-\mathrm{xs}$, among others (92). Bcl-2 homodimerizes with itself, and also forms heterodimers with Bax, which has the net effect of antagonzing Bax-induced cell death (93). Increased expression of Bcl-2 (and Bcl-xL) protects leukemic cells from a wide variety of cytotoxic agents, including ara-C (30). One of the actions of these anti-apoptotic proteins appears to be to prevent activation of the protease cascade involved in the regulation of apoptosis (94). Chief among these is the Yama protease (CPP32), whose substrates 


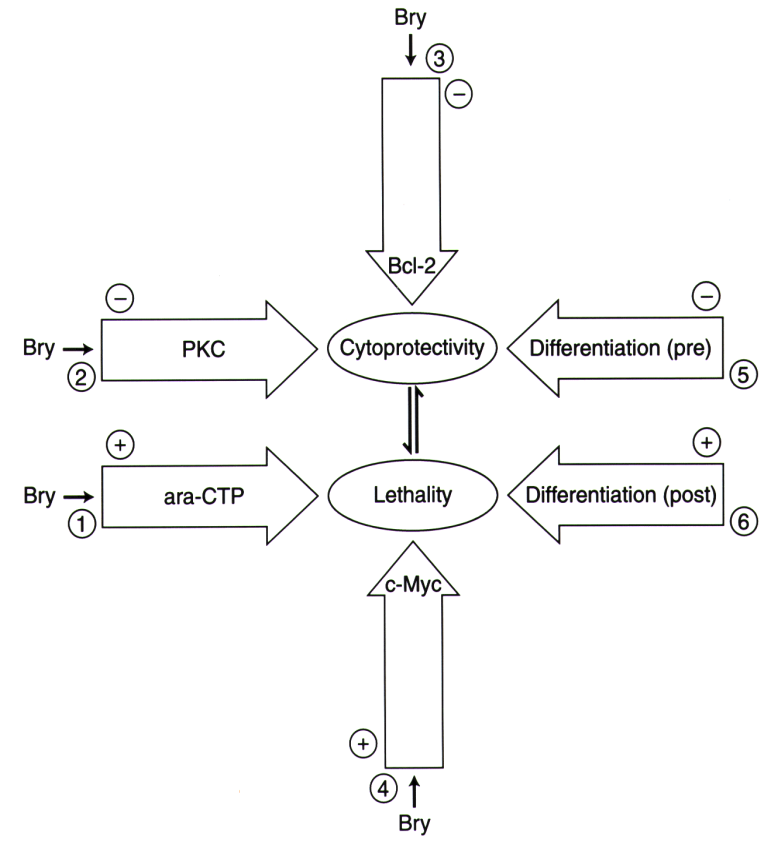

Figure 1 Summary of potential interactions between bryostatin 1 (Bry) and ara-C in relation to leukemic cell death. (1) Under some circumstances, bryostatin 1 may augment ara-C conversion to ara-CTP; (2) Chronic exposure to bryostatin 1 down-regulates PKC activity, thereby reducing its presumed cytoprotective effects; (3) Bryostatin 1 may phosphorylate $\mathrm{Bcl}-2$, potentially antagonizing its anti-apoptotic actions; (4) Bryostatin 1 may augment ara-C's lethal actions by permitting continued expression of c-Myc; (5) Induction of leukemic cell differentiation in susceptible cells by bryostatin 1 prior to ara-C administration precludes potentiation of apoptosis; (6) In contrast, induction of differentiation by bryostatin 1 after ara-C promotes this process.

include nuclear lamin and poly(ADP-ribosyl) polymerase(95). Thus, overexpression of $\mathrm{Bcl}-2$ in human leukemia cells (HL-60) has been shown to prevent ara-Cmediated Yama activation and PARP degradation (96). It is noteworthy that the mitochondrial protein cytochrome $\mathrm{c}$ serves as a cofactor for Yama activation (97), and that Bcl2 blocks translocation of cytochrome $\mathrm{c}$ from mitochondria to cytosol in response to various apoptotic stimuli (98). In view of similarities in structure between $\mathrm{Bcl}-2 / \mathrm{Bcl}-\mathrm{xL}$ and certain bacterial pore-forming proteins (99), it is tempting to postulate that $\mathrm{Bcl}-2$ and $\mathrm{Bcl}-\mathrm{xL}$ act to block mitochondrial channels permitting cytosolic redistribution of cytochrome c, thereby preventing activation of the apoptotic protease cascade.

In hematopoietic cells, expression of $\mathrm{Bcl}-2$ is linked to differentiation state. For example, as myeloid hematopoietic cells mature, expression of $\mathrm{Bcl}-2$ declines (100). This phenomenon may account for apoptosis occurring in leukemic cells undergoing maturation in response to differentiation-inducing agents such as retinoic acid or dexamethasone $(101,102)$. In fact, potentiation of ara-C-mediated apoptosis in human myeloid leukemia cells by differentiation-inducing stimuli has been attributed to Bcl-2 down-regulation (102). In addition, induction of maturation in lymphoid leukemia cells by bryostatin 1 has also been reported to result in decreased expression of Bcl-2 (103). In the human promyelocytic leukemia (HL-60) cell however, bryostatin 1 does not down-regulate Bcl-2 expression, at least over an initial 24hr period, nor does it increase expression of Bax (104). Instead, bryostatin 1 up-regulates expression of the antiapoptotic protein, Mcl-1. This suggests that the ability of bryostatin 1 to facilitate ara-C-related apoptosis in these cells involves factors other than a reduction in expression of the Bcl-2 protein.

Recently, phosphorylation of $\mathrm{Bcl}-2$ and related proteins (e.g., BAD) has been proposed as a posttranslational mechanism by which cell death may be regulated (105). For example, exposure of cells to taxol and other microtubule-active agents has been associated with Bcl-2 phosphorylation (106), and this event has been postulated to contribute to the induction of cell death (107). In the case of prostate cancer cells, taxol-associated phosphorylation of $\mathrm{Bcl}-2$ is accompanied by reduced heterodimerization with Bax, providing a possible mechanism by which cell death may be facilitated (108). Interestingly, bryostatin 1 has been shown to induce phosphorylation of $\mathrm{Bcl}-2$ in $32 \mathrm{D}$ hemtoapoieitic cells, although this phenomenon was associated with resistance to growth factor-induced apoptosis (109). In contrast, treatment with bryostatin 1 effectively restores the ability of ara-C to induce apoptosis in HL-60/Bcl-2 overexpressing cells to wild-type levels, an event associated with $\mathrm{Bcl}-2$ phosphorylation (110). In addition, bryostatin 1 administration prevented Bcl-2 from blocking ara-C-mediated CPP32 activation and PARP cleavage. The differential effect of bryostatin 1 on apoptosis in these two systems may stem from (1) divergent effects in normal versus neoplastic cells; (2) different cell death-inducing stimuli (e.g., growth factor deprivation versus exposure to a cytotoxic agent); (3) phosphorylation site-specific events; or a combination of these factors. In any event, these findings suggest that post-translational modifications of Bcl-2 induced by bryostatin 1 may contribute to the ability of this agent to potentiate drug-induced apoptosis in leukemia.

\section{FUTURE DIRECTIONS}

The completion of phase I trials of bryostatin 1 (39-41) has set the stage for the development of successor studies in which bryostatin 1 and related compounds will be combined with other agents, based upon their ability to facilitate apoptosis. For example, the PKC inhibitor safingol has recently been reported to enhance mitomycin $\mathrm{C}$-induced apoptosis in gastric cancer cells (111). This suggests that interruption of the PKC pathway, either by down-regulation or direct inhibition, may promote 
apoptosis in tumors of epithelial cell origin, and in response to agents other than ara-C.

\section{PERSPECTIVES}

The macrocyclic lactone PKC activator bryostatin 1 represents a member of class of antineoplastic agents that exert their antitumor, immunomodulatory, and chemomodulatory actions through induction of perturbations in intracellular signalling pathways. There is now accumulating evidence that bryostatin 1 increases the susceptibility of myeloid leukemia cells to ara-C-mediated apoptosis, an event that is both dose- and sequencedependent. This phenomenenon may involve multiple mechanisms, including alterations in ara-C metabolism, activation of specific PKC isoforms, down-regulation of PKC activity, induction of imabalances between stressand survival -related signalling pathways, dysregulation of cell cycle-related genes (e.g., c-Myc), and phosphorylation of Bcl-2. A summary of these interactions is illustrated in Figure 1. An improved understanding of the mechanisms by which agents such as bryostatin 1 lower the threshold for cytotoxic drug-mediated apoptosis in leukemia may provide a rationale framework for the design of entirely novel chemotherapeutic regimens in the treatment of both hematologic and non-hematologic malignancies.

\section{ACKNOWLEDGEMENTS}

This work was supported by RO1CA 63753 from the NCI, and a Translational Research Award from the Leukemia Society of America.

\section{REFERENCES}

1. Wyllie, A.H., Kerr, J.F.R., Currie, A.R. Cell death: the significance of apoptosis. Int. Rev. Cytol. 68, 251-306 (1980)

2. Lotem, J., Cragoe, E., Sachs, L. Rescue from programmed cell death in leukemia and normal cells. Blood 78 , 953-60 (1991).

3. Oberhammer, F., Wilson, J.W., Dive, C., Morris, I.D., Hickman, J.A., Wakeling, A.E., Walker, R.P., Sikorska, M. Apoptotic death in epithelial cells: cleavage of DNA to 300 or $50 \mathrm{~kb}$ fragments prior to or in the absence of internucleosomal fragmentation. EMBO J 12, 3679-3684 (1993).

4. Kaufmann S. Induction of endonucleolytic DNA cleavage in human acute myeloid leukemia cells etoposide, camptothecin, and other cytotoxic anticancer drugs: a cautionary note. Cancer Res 48, 5870-5878 (1989).

5. Gorczyca, W., Bigman, K., Mittelman, A., Ahmed, T., Gong, J., Melamed, M.R., Darzynkiewicz, Z. Induction of
DNA strand breaks associated with apoptosis during treatment of leukemias. Leukemia 7, 659-70 (1993).

6. Grant, S., Lehman, C., Cadman, E. Enhancement of 1- $\beta$ -D-arabinofuranosylcytosine accumulation within L1210 cells and increased cytotoxicity following thymidine exposure. Cancer Res.40, 1525-1531 (1980).

7. Nishizuka, Y. The role of protein kinase $\mathrm{C}$ in cell surface signal transduction and tumour promotion. Nature 308, 693-698 (1984)

8. Grant S, Jarvis D, Swerdlow P, Turner A, Traylor R, Wallace H, Lin, P-S, Pettit GR, Gewirtz DA: Potentiation of the activity of $1-\beta-D$-arabinofuranosylcytosine by the macrocyclic lactone PKC activator bryostatin 1 is associated with enhanced fragmentation of mature DNA. Cancer Res 52, 6270-78 (1992)

9. Jarvis WD, Gewirtz DA, Povirk L, Turner A, Traylor R, Pettit GR, Grant S: Effect of bryostatin 1 and other activators of protein kinase $C$ on 1- $\beta$-Darabinofuranosylcytosine-induced apoptosis in HL-60 human promyelocytic leukemia cells. Biochem Pharmacol 47, 839-52 (1994)

10. Mastrianni, D.M., Tung, N.M., Tenen, D.G. Acute myelogenous leukemia: current treatment and future directions. Am. J. Med. 82, 286-295 (1992)

11. Plagemann, P.G.W., Marz, R., Wolheuter, R.M. Transport and metabolism of deoxycytidine and 1- $\beta$-Darabinofuranosylcytosine into cultured Novikoff rat hepatoma cells, relationship to phosphorylation, and regulation of triphosphate synthesis. Cancer Research 38, 978-989 (1978)

12. Durham, J.P., Ives, D.H. Deoxycytidine kinase. II. Purification and general properties of the calf thymus enzyme. J. Biol. Chem. 245 , 2276-2284 (1970)

13. Wang, L.M., Kucera, G.L. Deoxycytidine kinase is phosphorylated in vitro by protein kinase $\mathrm{C}-\alpha$. Biochim. Biophys. Acta. 1224, 161-167 (1994)

14. Steuart, C.D., Burke, P.J. Cytidine deaminase and the development of resistance to arabinosyl cytosine. Nature New Biol. 233, 109-110 (1971)

15. Furth, J.J., Cohen, S.S. Inhibition of mammalian DNA polymerase by the 5 '-triphosphate of $1-\beta$-Darabinofuranosylcytosine and the 5'-triphosphate of 1- $\beta$-Darabinofuranosyladenine. Cancer Res.28, 2061-2067 (1968)

16. Major, P.P., Egan, E., Herrick, D.J., Kufe, D.W. Effect of ara-C incorporation on deoxyribonucleic synthesis in cells. Biochem. Pharmacol. 31, 2937-2940 (1982) 
17. Kufe, D.W., Major, P.P., Egan, M., Beardsley, P. Incorporation of ara-C into L1210 DNA as a correlate of cytotoxicity. J. Biol. Chem. 255 , 8997-9000 (1981)

18. Kucera, G.L., Capizzi, R.L. 1- $\beta$-Darabinofuranosylcytosine-diphosphate-choline is formed by the reversal of cholinephosphotransferase and not via cytidylyltransferase. Cancer Res. 52, 3886-3891(1992)

19. Kharbanda, S., Datta, R., Kufe, D. regulation of c-jun gene expression in HL-60 luekemia cells by 1- $\beta$-Darabinofuranosylcytosine. Potential involvement of a protein kinase C-dependent mechanism. Biochemistry 30, 7947-7952 (1991)

20. McConkey, D.J., Hartzell, P., Jondal, M., Orrenius, S. Inhibition of DNA fragmentation in thymocytes and isolated thymocyte nuclei by agents that stimulate protein kinase C. J Biol Chem 264, 13399-13402 (1989)

21. Strum, J.C., Small, G.W., Pauig, S.B., Daniel, L.W. 1-D-arabinofuranosylcytosine stimulates ceramide and diglyceride formation in HL-60 cells. J. Biol. Chem. 269, 15493-15497 (1994)

22. Y.A. Hannun. Functions of ceramide in coordinating cellular responses to stress. Science 274:1855-1858 (1996)

23. Jarvis, W.D., Kolesnick, R.W., Fornari, F.A., Traylor, R.S., Gewirtz, D.A., Grant, S. Activation of the sphingomyelinase pathway initiates apoptosis in a variety of mammalian cell lines. Proc. Natl. Acad. Sci. USA 91, 73-77 (1994)

24. Wiley, J.S., Jones, S.P., Sawyer, W.H., Paterson, A.R.P. Cytosine arabinoside influx and nucleside tranport sites in acute leukemia. J. Clin. Invest. 69, 479-489 (1982)

25. Bhalla, K.R., Nayak, R., Grant, S. Isolation and characterization of a deoxycytidine kinase-deficient human promyelocytic leukemic cell line highly resistant to $1-\beta-D-$ arabinofuranosylcytosine. Cancer Res. 44, 5029-5037 (1984)

26. Steuart, C.D., Burke, P.J. Cytidine deaminase and the development of resistance to arabinosyl cytosine. Nature New Biol. 233, 109-110 (1971).

27. Abe, I., Saito, S., Hori, K., Suzuki, M., Sato, H. Role of dephosphorylation in accumulation of 1- $\beta-\mathrm{D}$ arabinofuranolsylcytosine 5'-triphosphate in human lymphoblastic cell lines with reference to their drug sensitivity. Cancer Res. 42, 2846-2851 (1982)

28. de St. Vincent, Buttin, G. Studies on 1- $\beta$-Darabinofuranosylcytosine-resistant mutants of chinese hamster fibroblasts: II Joint resistance to arabinofuranosyl cytosine and to excess thymidine- a semi-dominant manifestation of deoxycytidine triphosphate pool expansion. Somat. Cell Genet. 5, 162-167 (1979).

29. Major, P.P., Egan, E.M., Beardsley, G.P., Minden, M.E., Kufe, D.W. Lethality of human myeloblasts correlates with the incorporation of arabinofuranosylcytosine int DNA. Proc. Natl. Acad. Sci. USA. 78, 3235-3239 (1981)

30. Miyashita, T., Reed, J.C. Bcl-2 oncoprotein blocks chemotherapy-induced apoptosis in human leukemia cell line. Blood 81, 151-157 (1993)

31. Manome, Y., Weichselbaum, R.R., Kufe, D.W., Fine, H.A. Effect of Bcl-2 on ionizing radiation and 1- $\beta$-Darabinofuranosylcytosine-induced internucleosomal DNA fragmentation and cell survival in human myeloid leukemia cells. Oncol. Res. 5, 139-144 (1993)

32. Ibrado, A.M., Huang, Y., Fang, G., Liu, L., Bhalla, K. Overexpression of Bcl-2 or Bcl-xL inhibits ara-C-induced CPP32/Yama protease activity and apoptosis of human acute myelogenous leukemia HL-60 cells. Cancer Res. 56, 4743-4748 (1996).

33. Bullock, G., Ray, S., Reed, J.C., Krajewski, S., Ibrado, A.M., Huang, Y., Bhalla, K. Intracellular metabolism of ara-C and resulting DNA fragmentation and apoptosis of human AML HL-60 cells possessing disparate levels of Bcl-2 protein. Leukemia 10, 1731-1741 (1996)

34. Pettit G.R., Herald C.L., Boubek D.L., Herald D.L., Arnold E., Clardy, J.: Isolation and structure of bryostatin 1. J Am Chem Soc 104,6846-6948 (1982)

35. Kennedy, M.J., Prestigiacomo, L.J., Tyler, G., May, W.S., Davidson, N.E. Differential effects of bryostatin 1 and phorbol ester on human breast cancer cell lines. Cancer Res.52,1278-83 (1992).

36. Basu, A., Lazo, J.S. Sensitization of human cervical cancer cells to cis-diamminechloroplatinum(II) by bryostatin 1. Cancer Res.52 , 3119-3124 (1992)

37. Hornung, R.L., Pearson, J.W., Beckwith, M., Longo, D.L. Preclinical evaluation of bryostatin as an anticancer agent against several tumor cell lines: in vitro versus in vivo activity. Cancer Res. 52, 101-107 (1992)

38. L.M. Schucter, A.H. Esa, W.S. May, M.K. Laulis, G.R. Pettit, A.D. Hess. Successful treatment of murine melanoma with bryostatin 1. Cancer Res. 51,682687 (1991)

39. Jayson, G.C., Crowther, D., Prendiville, J., McGown, A.T., Scheid, C., Stern, P., Young, R., Brenchley, P., Chang, J., Owens, S., Pettit, G.R. A phase I trial of bryostatin 1 in patients with advanced malignancy using a 
24 hour intravenous infusion. Br. J. Cancer 72,461-8 (1995)

40. Philip, P., Rea, D., Thavasu, P., Carmichael, J., Stuart, N.S.A., Rockett, H., Talbot, D.C., Ganesan, T., Pettit, G.R., Balkwill, F., Harris, A.L. Phase I study of bryostatin 1: assessment of interleukin-6 and tumour necrosis factor in vivo. J Natl Cancer Inst 85, 1812-1818 (1993)

41. Prendiville J., Crowther D., Thatcher, N., Woll, P.J., Fox, B.W., McGown, A., Stern, P., McDermott, R., Potter, M., Pettit, G.R. A phase I study of intravenous bryostatin 1 in patients with advanced cancer. Br J Cancer 68, 418-424 (1993)

42. Berkow, R.L., Kraft, A.S., Bryostatin, a non-phorbol ester macrocyclic lactone, activates intact human polymorphonuclear leukocytes and binds to the phorbol ester receptor. Biochem. Biophys. Res. Commun. 131, 1109-16 (1985)

43. Drexler, H.G., Gignac, S.M., Jones, R.A., Scott, C.S., Pettit, G.R., Hoffbrand, A.V. Bryostatin 1 induces differentiation of B-chronic lymphocytic leukemia cells. Blood 74, 1747-54 (1989).

44. Hennings, H., Blumberg, P.M., Petit, G.R., Herald, C.L., Shores, R.A., Yuspa, S.H. Bryostatin 1, an activator of protein kinase $\mathrm{C}$, inhibits tumor promotion by phorbol esters in SENCAR mouse skin. Carcinogenesis 8, 13431346 (1987)

45. Kraft, A.S., Smith, J.B., Berkow, R.L. Bryostatin, an activator of the calcium phospholipid-dependent protein kinase, blocks phorbol ester-induced differentiation of human promyelocytic leukemia cells HL-60. Proc Natl Acad Sci USA 83, 1334-38 (1986)

46. Szallasi, Z., Smith, C.B., Pettit, G.R., Blumberg, P.M. Differential regulation of protein kinase $\mathrm{C}$ isozymes by bryostatin 1 and phorbol 12-myristate 13-acetate in NIH 3T3 fibroblasts. J. Biol. Chem 269, 2118-24 (1994)

47. Hocevar, B.A., Fields, A.P. Selective translocation of II-protein kinase $\mathrm{C}$ to the nucleus of human promyelocytic leukemia cells. J. Biol. Chem. 266, 28-33 (1991).

48. Isakov, N., Galron, D., Mustelin, T., Pettit, G.R., and Altman, A. Inhibition of phorbol ester-induced $\mathrm{T}$ cell proliferation by bryostatin 1 is associated with rapid degradation of protein kinase C. J. Immunol. 150, 11951204 (1993)

49. Lee, H-W., Smith, L., Pettit, G.R., Vinitsky, A., Smith, J.B. Ubiquitinization of protein kinase C- and degradation by the proteosome. J. Biol. Chem. 271, 2097320976 (1996)
50. Kraft, A.S., Williams, F., Pettit, G.R., Lilly, M.B. Varied differentiation responses of human leukemias to bryostatin 1. Cancer Res 49, 1287-93 (1989)

51. Stone, R.M., Sariban, E., Pettit, G.R., Kufe, D.W. Bryostatin 1 activates protein kinase $\mathrm{C}$ and induces monocytic differentiation of HL-60 cells. Blood 72, 208213 (1998)

52. Asiedu, C., Biggs, J., Lilly, M., Kraft, A.S. Inhibition of leukemic cell growth by the protein kinase $\mathrm{C}$ activator bryostatin 1 correlates with the dephosphorylation of cyclin-dependent kinase 2. Cancer Res 55, 3716-20 (1995).

53. Jones, R., Sharkis, S., Miller, C., Rowinsky, E., Burke, P., and May, W.S. Bryostatin 1, a unique biologic response modifier: antileukemic activity in vitro. Blood 75, 1319-1323 (1990)

54. Grant, S., Traylor, R., Bhalla, K., McCrady, C., Pettit, G.R. Effect of a combined exposure to ara-C, bryostatin 1, and rGM-CSF on the in vitro clonogenic growth of normal and leukemic human hematopoietic progenitor cells. Leukemia 5, 432-439 (1993)

55. May, W.S., Sharkis, S.S., Esa, A.H., Gebbia, V., Kraft, A.S., Pettit, G.R. \& Sensenbrenner, L.L. Antineoplastic bryostatins are multipotent stimulators of human hematopoietic progenitor cells. Proc Natl Acad Sci(USA) 84, 8483-8487 (1987)

56. Li, F., Grant, S., Pettit, G.R., McCrady, C. Effect of pharmacologic manipulation of protein kinase $\mathrm{C}(\mathrm{PKC})$ on the proliferation and lineage specificity of progenitor cellenriched normal human bone marrow cells (MY-10+) exposed to rGM-CSF and rIL-3. Blood 80, 2495-2502 (1992).

57. Sharkis, S.J., Jones, R.J., Bellis, M.L., Demetri, G.D., Griffin, J.D., Civin, C., May, W.S. The action of bryostatin 1 on normal human hematopoietic progenitors is mediated by accessory cell release of growth factors. Blood 76, 716-721 (1990)

58. Nara, N., Curtis, J.E., Senn, J.S., Pritchler, D.L., McCulloch, E.A. The sensitivity to cytosine arabinoside of the blast progenitors of acute myeloblastic leukemia. Blood 67, $762-769$ (1986)

59. Curtis, J.E., Messner, H.A., Hasselhock, R., Elkahem, T.M., McCulloch, E.A. Contributions of host and diseaserelated attributes to the outcome of patients with acute myelocytic leukemia (AML). Blood 2, 253-259 (1984)

60. Huang, Y., Waxman, S. Enhanced apoptosis in leukemia cells following treatment with combination fluoropyrimdines and differentiation inducers. Mol. Cell. Differ. 2, 83-100 (1994.) 
61. Studzinski, G.P., Reddy, K.B., Hill, H.Z., Bhandal, A.K. Potentiation of $1-\beta$-D-arabinofuranosylcytosine cytotoxicity by 1,25 -dihydroxyvitamin $\mathrm{D}_{3}$ correlates with reduced rate of maturation of DNA replication intermediates. Cancer Res. 51, 3451-55 (1991)

62. Bhatia, U., Traganos, F., Darzynkiewicz, Z. Induction of cell differentiation potentiates apoptosis triggered by prior exposure to DNA-damaging drugs. Cell Growth Diff. 6, 937-44 (1995)

63. Waxman, S., Huang, Y., Scher, B.M., Scher, W. Combination cytotoxic-differentiation therapy of mouse erythroleukemia cells with 5-fluorouracil and hexamethylene bisacetamide. Cancer Res. 50, 3878-3887 (1990)

64. Grant, S., Jarvis, W.D., Turner, A.J., Wallace, H., Pettit, G.R. Effect of bryostatin 1 and rGM-CSF on the metabolism of $1-\beta$-D-arabinofuranosylcytosine in human leukemic myeloblasts. British Journal of Haematology 82, 522-528 (1992)

65. Grant, S., McCrady, C., Boise, L., Westin, E., Pettit, G.R. Effects of bryostatin 1 on the metabolism and cytoxicity of 1- $\beta$-D-arabinofuranosylcytosine in human leukemia cells. Biochemical Pharmacol 42, 853-867 (1991)

66. Grant S, Jarvis D, Swerdlow P, Turner A, Traylor R, Wallace H, Lin, P-S, Pettit GR, Gewirtz DA: Potentiation of the activity of $1-\beta$-D-arabinofuranosylcytosine by the macrocyclic lactone PKC activator bryostatin 1 is associated with enhanced fragmentation of mature DNA. Cancer Res 52, 6270-6278 (1992).

67. Jarvis WD, Gewirtz DA, Povirk L, Turner A, Traylor R, Pettit GR, Grant S: Effect of bryostatin 1 and other activators of protein kinase $C$ on 1- $\beta-D-$ arabinofuranosylcytosine-induced apoptosis in HL-60 human promyelocytic leukemia cells. Biochem Pharmacol 47, 839-852 (1994)

68. Forbes, I.J., Zalewski, P.D., Giannakis, C., Cowled, P.A. Induction of apoptosis in chronic lymphocytic leukemia cells and its prevention by phorbol ester. Exp. Cell Res. 198, 367-372 (1992)

69. Bertrand, R., Solary, E., O'Connor, P., Kohn, K.W., Pommier, Y. Induction of a common pathway of apoptosis by staurosporine. Exp Cell Res 211, 314-321 (1994)

70. Grant, S., Turner, A., Bartimole, T.M., Nelms, P., Joe, V.C., Jarvis, W.D. . Modulation of 1- $\beta$-Darabinofuranosylcytosine-induced apoptosis in human promyelocytic leukemia cells by staurosporine and other inhibitors of protein kinase C. Oncology Research 6, 8799 (1994)
71. Kyriakis, J.M., Banerjee, P., Nikolakaki, E., Dai, T., Rubin, E.A., Ahmand, M.F., Avruch, J., Woodgett, J.R. The stress-activated protein kinase subfamily of c-Jun kinases. Nature(Lond.) 369, 156-160 (1994)

72. Cano, E., Mahadevan, L.C. Parallel signal processing among mammalian mitogen-activated protein kinases. Trends Biol. Sci. 20, 117-122 (1996)

73. Cuvillier, O., Pirianov, G., Kleuser, B., Vanek, P.G., Coso, O.A., Gutkind, J.S., Spiegel, S. Suppression of ceramide-mediated programmed cell death by sphingosine1-phosphate. Nature 381, 800-803 (1996)

74. Xia, Z., Dickens, M., Raingeaud, J., David, R.J., Greenberg, M.E. Opposing effects of ERK, JNK, and RK kinases on apoptosis. Science 270, 1326-1331 (1995)

75. Martin, S.J., Bradley, J.G., Cotter, T.G. HL-60 cells differentiate towards neutrophils subsequently die via apoptosis. Clin Exp Immunol 79, 448-453 (1990)

76. Solary, E., Bertrand, R., Pommier, Y. Apoptosis of human leukemic HL-60 cells induced to differentiate by phorbol ester treatment. Leukemia 8, $792-797$ (1994)

77. Solary, E., Bertrand, R., Kohn, K., Pommier, Y. Differential induction of apoptosis in undifferentiated and differentiated HL-60 cells by DNA topoisomerase I and II inhibitors. Blood 81, 1359-1368 (1993).

78. de Vente, J., Kiley, S., Garris, T., Bryant, W., Hooker, J., Posekany, K., Parker, P., Cook, P., Fletcher, D., Ways, D.K. Phorbol ester treatment of U937 cells with altered protein kinase $\mathrm{C}$ content and distribution induces cell death rather than differentiation. Cell Growth Diff. 6, 71382 (1995)

79. Selvakumaran, M., Reed, J.C., Liebermann, D., Hoffman, B. Progression of the myeloid differentiation program is dominant to transforming growth factor- 1induced apoptosis in M1 myeloid leukemia cells. Blood 84, 1036-1042 (1994)

80. Grant, S., Rao, A., Freemerman, A.J., Turner, A.J., Kornstein, M.J., Chelliah, J., Jarvis, W.D. Divergent effects of calcium ionophore (A23187) on bryostatin 1related differentiation and apoptosis in human promyelocytic leukemia cells (HL-60). Mol. Cell Diff. 3, 337-359 (1995)

81. Rao, A.S., Freemerman, A.J., Jarvis, W.D., Chelliah, J., Bear, H.D., Mikkelsen, R., Grant, S. Effects of AS101 on bryostatin 1-mediated differentiation induction, cell cycle arrest, and modulation of drug-induced apoptosis in human myeloid leukemia cells. Leukemia 10, 1150-1158 (1996) 
82. Huang, Y., Waxman, S. Enhanced apoptosis in leukemia cells following treatment with combination fluoropyrimidines and differentiation inducers. Mol Cell Diff 2, 83-100 (1994)

83. Studzinski, G.P., Reddy, K.B., Hill, H.Z., Bhandal, A.K. Potentiation of $1-\beta$-D-arabinofuranosylcytosine cytotoxicity to HL-60 cells by 1,25-dihydroxyvitamin D3 correlates with reduced rate of maturation of DNA replication intermediates. Cancer Res 51, 3451-3455 (1991).

84. Bhatia, U., Traganos, F., Darzynkciewicz, Z. Induction of cell differentiation potentiates apoptosis triggered by prior exposure to DNA damaging drugs. Cell Growth Diff 6, 937-944 (1995)

85. Grant, S., Turner, A.J., Freemerman, A.J., Wang, Z., Kramer, L., Jarvis, W.D. Modulation of protein kinase C activity and calcium-sensitive isoform expression in human myeloid leukemia cells by bryostatin 1 : relationship to differentiation and ara-C-induced apoptosis. Exp Cell Res 228, 65-75 (1996)

86. Kato G., Dang C.V. Function of the c-Myc oncoprotein. FASEB J 6, 3065-3072 (1992)

87. Galaktionov, K., Chen, X., Beach, D. Cdc25 cell-cycle phosphatase as a target of c-myc. Nature 382, 511-517 (1996)

88. Kraft AS, Baker VV, and May WS, Bryostatin 1 induces changes in protein kinase $\mathrm{C}$ location and activity without altering c-myc expression in human promyelocytic leukemia cells (HL-60). Oncogene 1, 111-118 (1987)

89. Askew DS, Ashmun RA, Simmons BC, and Cleveland JL, Constitutive c-myc expression in an IL-3-dependent myeloid cell line suppresses cell cycle arrest and accelerates apoptosis. Oncogene 6, 1915-1922 (1991)

90. Chelliah, J., Freemerman, A.J., Wu-Pong, S., Jarvis, W.D., Grant, S. Potentiation of ara-C-induced apoptosis by the protein kinase $\mathrm{C}$ activator bryostatin 1 in human leukemia cells (HL-60) involves a process dependent upon c-Myc. Biochemical Pharmacol. In Press.

91. Reed, J.C. Bcl-2 and the regulators of programmed cell death. J. Cell Biol. 124, 1-6 (1994).

92. Yang, E., Korsmeyer, S.J. Molecular thanatopsis: a discourse on the BCL2 family and cell death. Blood 88, 386-401 (1996)

93. Oltavi, Z.N., Milliman, C.L., and Korsmeyer, S.J. Bcl2 heterodimerizes in vivo with a conserved homolog, Bax, that accelerates programmed cell death. Cell 74, 609-619 (1993)
94. Chinnaiyan, A.M., Orth, K., O'Rourke, K., Duan, H., Poirer, G.G., Dixit, V.M. Molecular ordering of the cell death pathway: bcl-2 and bcl-xL function upstream of the CED-3-like apoptotic proteases. J. Biol. Chem. 271, 45734576 (1996)

95. Tewari, M., Quan, L.T., O'Rourke, K., Desnoyers, S., Zeng, Z., Beidler, D.R., Poirer, G.G., Salvesan, G.S., Dixit, V.M. Yama/CPP32, a mammalian homolog of CED-3, is a Crm-inibitable protease that cleaves the death substrate poly(ADP-ribose)polymerase. J. Biol. Chem. 267, 30761-30764 (1994)

96. Ibrado, A.M., Huang, Y., Fang, G., Liu, L., Bhalla, K. Overexpression of Bcl-2 or Bcl-xL inhibits ara-C-induced CPP32/Yama protease activity and apoptosis of human acute myelogenous leukemia HL-60 cells. Cancer Res. 56, 4743-4748 (1996)

97. Liu, X., Kim, C.N., Yang, J., Jemmerson, R., Wang, $\mathrm{X}$. Induction of apoptotic program in cell-free extracts: requirement for dATP and cytochrome c. Cell 86, 147-157 (1996)

98. Yang, J., Liu, X., Bhalla, K., Kim, C.N., Ibrado, A.M., Cai, J., Peng, T-I, Jones, D.P., Wang, X. Prevention of apoptosis by Bcl-2: release of cytochrome c from mitochondria blocked. Science 275, 1129-1132 (1997)

99. Minn, A.J., Velez, P., Schendel, S.L., Liang, H., Muchmore, S.W., Fesik, S.W., Fill, M., Thompson, C.B. Bcl-xL forms an ion channel in synthetic lipid membranes. Nature 385, 353-357 (1997)

100. Delia, D., Aiello, A., Soligo, D., Fontanella, E., Melani, C., Pezzela, F., Pierotti, M.A. Della Porta, G. $\mathrm{Bcl} 2$ proto-oncogene expression in normal and neoplastic human myeloid cells. Blood 79, 1291-1297 (1992)

101. Hu, Z-B., Minden, M.D., McCulloch, E.A. Direct evidence for the participation of bcl-2 in the regulation by retinoic acid of the ara-C sensitivity of leukemic stem cells. Leukemia 9, 1667-1673 (1995)

102. Lotem, J., Sachs, L. Regulation of bcl-2, bcl-xL, and bax in the control of apoptosis by hematopoietic cytokines and dexamethasone. Cell Growth Diff. 6, 647-653 (1995)

103. Maki, A., Diwkaran, H., Redman, B., Al-Asfar, S., Pettit, G.R., Mohammad, R.M., Al-Katib, A. The bcl-2 and p53 oncoproteins can be modulated by bryostatin 1 and dolostatins in human large cell lymphoma. AntiCancer Drugs 6, 392-397 (1995)

104. Bartimole, T.M., Vrana, J.A., Freemerman, A.J., Jarvis, W.D. Reed, J.C., Boise, L.H., Grant, S. Modulation of the expression of Bcl-2 and related proteins in human leukemia cells by protein kinase $\mathrm{C}$ activators: relationship 
to effects on 1- $\beta$-D-arabinofuranosylcytosine-induced apoptosis. Cell Death Diff 4, 294-303 (1997)

105. Gajewski, T.F., Thompson, C.B. Apoptosis meets signal transduction: elimination of a BAD influence. Cell 87, 589-592 (1996)

106. Haldar, S., Jena, N., Croce, C.M. Inactivation of Bcl2 by phosphorylation. Proc. Natl. Acad. Sci. (USA) 92, 4352-4356 (1995)

107. Blagsklonny, M.V., Giannakakou, P., El-Diery, W.S., Kingston, D.G.I., Higgs, P.I.,Neckers, L., Fojo, T. Raf1/bcl-2 phosphorylation: a step from microtubule damage to cell death. Cancer Res. 57, 130-135 (1997)

108. Haldar, S., Chintapalli, J., Croce, C.M. Taxol induces bcl-2 phosphorylation and death of prostate cancer cells. Cancer Res. 56, 1253-1255 (1996)

109. May, W.S., Tyler, G., Ito, T., Armstrong, D.K., Qatsha, K.A., Davidson, N.E. Interleukin-3 and bryostatin 1 mediate hyperphosphorylation of BCL2 in association with suppression of apoptosis. J. Biol. Chem 269, $26865-$ 26870 (1994)

110. Grant, S., Wang, S., Vrana, J., Bartimole, T., Krystal, G., Jarvis, W.D., Dent, P. Reversal of Bcl-2-mediated resistance to ara-C-mediated apoptosis in human myeloid leukemia cells by down-regulation or inhibition of protein kinase C. Proc. Am. Assoc. Cancer Res. 38, 620 (1997)

111. Schwartz, G.K., Haimovitz-Friedman, A., Dhupar, S.K., Ehlieter, D., Maslak, P., Lai, L., Loganzo, F., Kelsen, D.P. Potentiation of apoptosis by treatment with the protein kinase $\mathrm{C}$-specific inhibitor safingol in mitomycin C-treated gastric cancer cells. J. Natl. Cancer Inst. 87, 1394-1399 (1995) 